\title{
Karl Landsteiner (1868-1943): Originator of ABO blood classification
}

\author{
Siang Yong $\underline{\operatorname{Tan}}^{1}, \mathrm{MD}, \mathrm{JD}$, Connor $\underline{\mathrm{Graham}}^{2}$, MD
}

I magine practising medicine without access to blood transfusions. It was Karl Landsteiner, a 1930 Nobel laureate, who classified human blood into groups based on the presence of naturally occurring agglutinating antibodies, and whose findings eventually established safe transfusion procedures. Prior to his discovery, patients in need of blood received transfusions from animals such as sheep or randomly selected human donors - usually with disastrous consequences. Landsteiner's discovery literally saved millions of human lives.

EARLY LIFE AND CAREER Karl Landsteiner was born on June 14, 1868 in a Jewish quarter referred to as Baden bei Wien, just south of Vienna, Austria. His father was a successful and well-known journalist who taught political science at the University of Lille. Tragically, his father died at age 57 when Landsteiner was only six. A precocious and model student, Landsteiner studied medicine at the University of Vienna, where he developed a love for organic chemistry. He was influenced by well-known physicians of his time, such as Theodor Billroth. Having graduated in 1891, Landsteiner first worked briefly with Otto Kahler, who described Kahler's Syndrome, known today as multiple myeloma, and

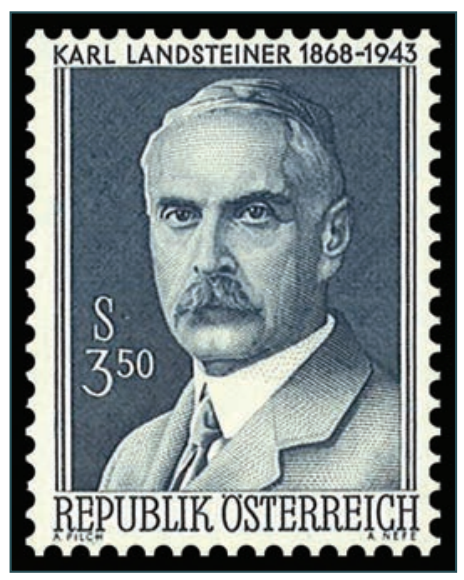

but frequently upon blood cells from other individuals as well". Although it was well recognised at the time that clumping would occur when blood from different animals was mixed, the idea that blood from two humans would cause the same reaction was novel. Landsteiner experimented with his own blood and that of five coworkers, first noting that none of the serum samples reacted with each individual's own red blood cells. However, coworker A's serum reacted with coworker B's red blood cells. This was due to the presence of B antigen on coworker B's red blood cells, which reacted with the naturally occurring antibody in coworker A's serum that was directed against the B antigen. Likewise, coworker B's serum reacted with coworker A's red
blood cells due to the presence of agglutinating antibody in coworker B's serum against the A antigen. Landsteiner concluded from these simple observations that there must be at least two different blood types or groups. Interestingly, his own serum reacted with both coworker A's and coworker B's red blood cells, from which he concluded that he must have both the anti-A antigen antibody as well as anti-B antigen antibody. This he called blood group $\mathrm{O}$, which is now recognised as the universal donor type. Landsteiner published these findings in a 1901 article entitled then spent the next five years working in different laboratories throughout Germany, one of which belonged to Emil Fischer, who won the Nobel Prize in 1902 for his work on organic synthesis of caffeine, glucose and oligopeptides. Landsteiner's early research dealt with visualising spirochaetes using dark-field microscopy and demonstrating that nerve tissue extracted from polio victims could paralyse Rhesus monkeys. These observations led to the conclusion that polio was caused by a transmissible virus, and opened the way for the eventual development of a serological diagnostic test.

ABO BLOOD GROUPS Landsteiner returned to Vienna in 1896 to work at the Hygiene Institute as an assistant to Max von Gruber, whose interest was in agglutination reactions. In 1900, Landsteiner published an article entitled "Anti-fermentative, lytic and agglutinating effects of blood serum and lymph". A footnote in the article hinted that "the serum of healthy humans has an agglutinating effect, not only upon animal blood cells,
"Agglutination phenomena of normal human blood". One year later, von Decastelo and Sturli, a former student, reported on a fourth blood group - $A B$, which is now recognised as the universal recipient blood type. Devoid of antibodies, serum from individuals with this blood group did not react with the red blood cells of other blood groups. Landsteiner, in conjunction with Alexander Wiener, would also subsequently discover the Rhesus factor that explains the pathophysiology of erythroblastosis fetalis.

Initially, Landsteiner's landmark discovery met with only lukewarm interest. Minimising its utility, Paul Ehrlich, a 1908 Nobel Prize winner, asked what sense it would make since "things are in the blood circulation directed against quite heterogeneous material which under normal circumstances can never come into the picture". In truth, Landsteiner himself had not fully grasped the lifesaving benefits of his discovery, meekly expressing the hope that his observations might somehow help explain the various consequences of blood transfusions. One reason may be that blood transfusions were impractical at

${ }^{1}$ Emeritus Professor of Medicine, University of Hawaii, ${ }^{2}$ Research carried out during medical residency at Hawaii Residency Program, University of Hawaii, Honolulu, Hawaii, USA

Correspondence: Prof Tan Siang Yong, 2230 Liliha Street, Suite 104, Honolulu, HI 96817, USA. siang@hawaii.edu 
the time because blood quickly coagulated in vitro, preventing its storage. When this problem was solved with the use of sodium citrate as an effective anticoagulant, the full scope of Landsteiner's discovery became evident. Safe blood transfusions following proper typing and crossmatching of test specimens from both donors and recipients transformed a clever observation into millions of lives saved.

LANDSTEINER THE PERSON Landsteiner was more comfortable with the solitary bench work of research than with human interactions. Indeed, he spent much of his life alone as a bachelor, and was 48 years old when he married Helen Wlasto. She gave him a son who was to later become a physician. Landsteiner was generally a nonconfrontational man. A passionate pianist, he was said to have sold off his piano simply because the neighbours had complained that it interfered with their listening to the radio. Yet this apparent peacemaking characteristic stood in sharp contrast to his obsession with religion. Landsteiner was born into the Jewish faith but converted to Catholicism, in part because it was expedient to do so. At the time, professorships in the Austrian-Hungarian Empire were only open to Catholics, so a university career would otherwise be impossible. He later worked for a Roman Catholic Hospital in the Netherlands, and even after moving to the United States in 1922, he continued to disavow his Jewish background. In 1937, a publication, Who's Who in American Jewry, listed his biography. Landsteiner filed a lawsuit for one hundred dollars against the publishers, stating that his parents were Jewish, but he had been of the Catholic faith since 1890.

Reportedly moody, even melancholic, Landsteiner was described as being "always crabby, always complaining". But he was also honest and revered for extreme modesty. For example, after winning the Nobel Prize in 1930, he suggested that his prize should have gone to Thomas Hunt Morgan for studies on sex-linked inheritance and chromosomal crossing. Dr Morgan would eventually win the Nobel Prize three years later. However,
Landsteiner's meekness is not to be confused with any lack of demanding standards. As a teacher and scientist, he was extremely critical and sceptical, often requiring his assistants to repeat their experiments right before his own eyes.

Landsteiner continued his research despite reaching the mandatory retirement age in 1939, and expended his final efforts researching malignant tumours after his wife was diagnosed with thyroid cancer. He soon realised that he was unlikely to find a cure in time, and he began to deteriorate both physically and mentally. He had expressed to a colleague his wish to die only after his wife's passing, but that was not to be. On June 26, 1943, he suffered a heart attack while working in his laboratory and died two days later. His wife, Helen, lived for another six months.

\section{BIBLIOGRAPHY}

- Chudley AE. Genetic landmarks through philately - Karl Landsteiner: the father of blood grouping. Clin Genet 2000; 57:267-9.

- Figl M, Pelinka LE. Karl Landsteiner, the discoverer of blood groups. Resuscitation 2004; 63:251-4.

- Haas LF. Karl Landsteiner (1868-1943). J Neurol Neurosurg Psychiatry 2002; 72:355.

- Kantha SS. The blood revolution initiated by the famous footnote of Karl Landsteiner's 1900 paper. Ceylon Med J 1995; 40:123-5.

- Kaufman M, Galishoff S, Savitt TL. Dictionary of American Medical Biography. Connecticut: Greenwood Press, 1984.

- Kyle RA, Shampo MA. Karl Landsteiner - discoverer of the major human blood groups. Mayo Clin Proc 2001; 76:830.

- Landsteiner K. Zur Kenntnis der antifermentativen, Iytischen und agglutinierenden Wirkungen des Blutserums und der Lymphe. Zbl Bakt 1900; 27:357-62. German.

- Landsteiner K. Über Agglutinationserscheinungen normalen menschlichen Blutes. Wien Klin Wochenschr 1901; 14:1132-4. German.

- McGrew RE. Encyclopedia of Medical History. New York: McGraw-Hill Book Company, 1985.

- Dr Karl Landsteiner. Bull Med Libr Assoc 1943; 31:374-5.

- Porter R. The Greatest Benefit to Mankind: A Medical History of Humanity. New York: WW Norton \& Company, 1997: 590-3.

- Schwarz HP, Dorner F. Karl Landsteiner and his major contributions to haematology. Br J Haematol 2003; 121:556-65.

- Sturgis CC. The history of blood transfusion. Bull Med Libr Assoc 1942; 30:105-12.

- Tagarelli A, Piro A, Lagonia P, Tagarelli G. Karl Landsteiner: a hundred years later. Transplantation 2001; 72:3-7.

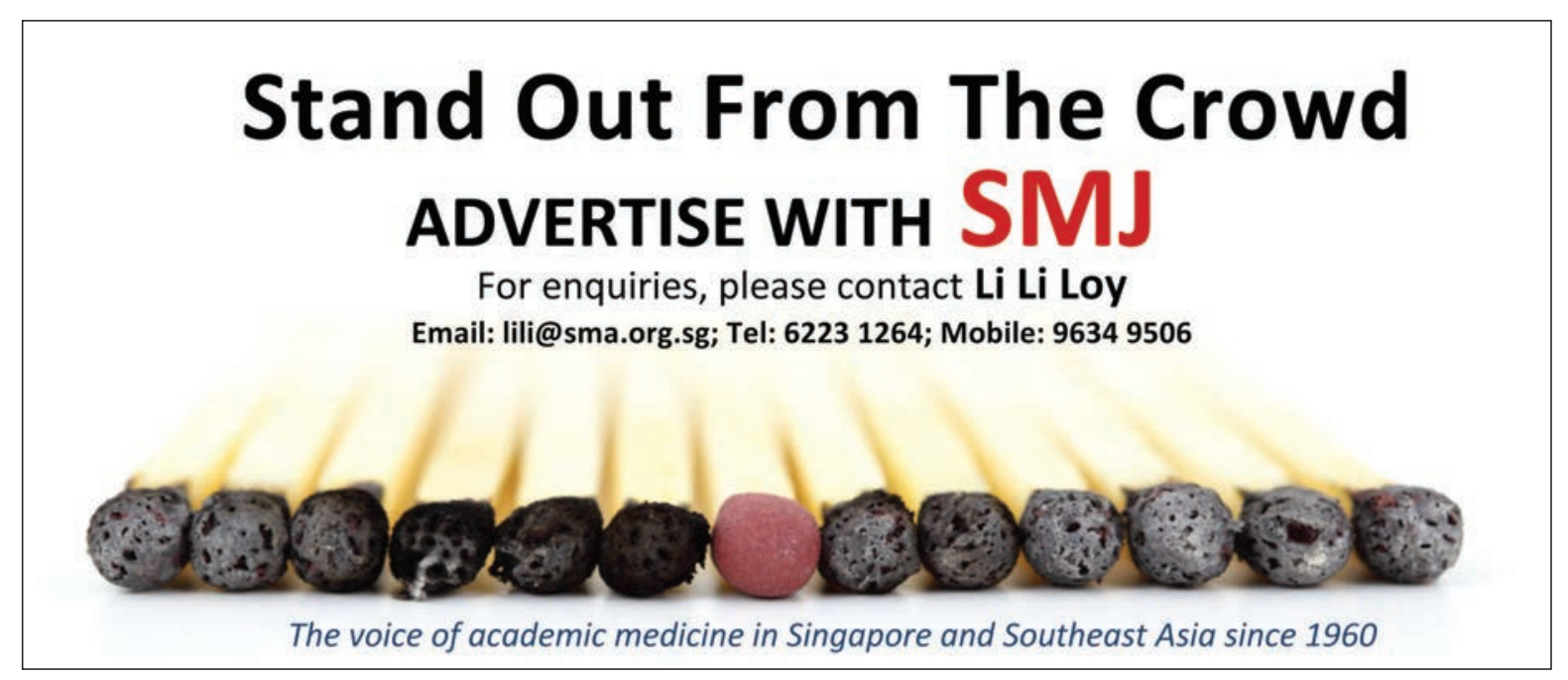

